\title{
Children's satisfaction and dissatisfaction with pain management in a Pediatric Emergency Department*
}

\author{
Satisfação e insatisfação da criança acerca do manejo da dor em um Pronto-Socorro Infantil \\ Satisfacción e insatisfacción del niño acerca del manejo del dolor en Urgencias Infantiles
}

Débora Astolfo de Lima², Lisabelle Mariano Rossatoํ, Danila Maria Batista Guedes ${ }^{1}$ Elaine Buchhorn Cintra Damião Lucía Silva², Regina Szylit ${ }^{1}$

How to cite this article:

Lima DA, Rossato LM, Guedes DMB, Damião EBC, Silva L, Szylit R. Children's satisfaction and dissatisfaction with pain management in a Pediatric Emergency Department. Rev Esc Enferm USP. 2018;52:e03373. DOI: http://dx.doi.org/10.1590/S1980-220X2017044503373

* Extracted from the dissertation: “A
satisfação da criança e da família acerca
do manejo da dor em um pronto-socorro
infantil”, Universidade de São Paulo, 2017.
${ }^{1}$ Universidade de São Paulo, Escola
de Enfermagem, Departamento de
Enfermagem Materno Infantil e
Psiquiátrica, São Paulo, SP, Brazil.
2 Universidade Federal de São Paulo, Escola
Paulista de Enfermagem, Departamento de
Enfermagem Pediátrica, São Paulo, SP, Brazil.

Corresponding author:

Lisabelle Mariano Rossato

Av. Dr. Enéas de Carvalho

Aguiar, 419 - Cerqueira César

CEP 05403-000 - São Paulo, SP, Brazil

rossato@usp.br

\begin{abstract}
Objective: To understand children's satisfaction and dissatisfaction with pain management in the pediatric emergency department. Method: Exploratory-descriptive qualitative study performed with children between 6 and 12 years of age and use of semistructured interviews and thematic analysis of data. Results: Nineteen children were interviewed. The results were organized in two themes: Theme 1 - Satisfaction perceived by children regarding pain management, which included three subthemes, namely: Priority care and quick pain relief, Basic needs met and Embracement by the team; and Theme 2 - Dissatisfaction perceived by children regarding pain management, which included three subthemes: Painful procedures, Uncomfortable environment and Delay in pain relief. Conclusion: Children's satisfaction with pain management was observed to be much more than pain relief or priority service, and also included the pediatric emergency department environment and embracement by the team. Care should be directed to children's singularities, that is, a care built from the understanding of the experience from children's point of view.
\end{abstract}

\section{DESCRIPTORS}

Pain; Child; Pain Management; Patient Satisfaction; Emergency Nursing Pediatric Nursing. 


\section{INTRODUCTION}

Despite advances in scientific studies in the area of pediatric pain, problems related to the evaluation and appropriate treatment of pain are still faced nowadays, which compromises the care provided to children, and causes their unnecessary suffering as a result of this inadequate evaluation ${ }^{(1-2)}$.

Research results show that inadequate pain management can have detrimental effects, such as long hospitalization, slower healing, depression, anxiety, and higher social and economic costs ${ }^{(3-5)}$.

Pain management is particularly important in scenarios such as the emergency department, which children may experience as stressors given their lack of knowledge of the hospital environment, the number of unknown people and separation and distancing from family members ${ }^{(6)}$.

The Pediatric Emergency Department (PED) is visited because of different complaints, among which pain stands out ${ }^{(6)}$. A study conducted at an urgency and emergency unit in the United States mentioned pain as one of the top five reasons for seeking the $\mathrm{PED}^{(7)}$. Similarly, in Brazil, pain is one of the main complaints of pediatric patients in the $\mathrm{PED}^{(8)}$. Despite the great demand for the service, it is known that children tend to receive less analgesia in pediatric emergency departments compared to adults with the same pain score ${ }^{(9)}$.

Pain assessment and management are two of the many variables related to children's satisfaction that need to be explored further. The authors propose the development of qualitative studies with the objective of increasing the understanding of children's satisfaction with pain management in the emergency department ${ }^{(5)}$.

When addressing children's population, it is known that everything seems more complicated. The first step in improving these patients' pain management is the accurate and systematic assessment of the actual care provided. This requires the identification of gaps in pain assessment and treatment, thus providing better results from the analysis of relevant evidence-based performance measures.

The assumption of a close correlation between pain relief and children's satisfaction would be convenient. In other words, for assuming that pain is well controlled, children will have to be satisfied.

The PED is an important setting for assessing children's satisfaction and dissatisfaction. It provides the first and only hospital service experience for many people and, as such, has been considered as a determining factor of the hospital's reputation $^{(10)}$.

In view of the above, the study question was: 'What is children's understanding of satisfaction and dissatisfaction with the management of their pain after being assisted in a pediatric emergency department?'. The objective was to understand satisfaction and dissatisfaction with pain management in the pediatric emergency department from the children's point of view.

\section{METHOD}

This is an exploratory-descriptive qualitative study involving semi-structured interviews and thematic analysis of data ${ }^{(11-17)}$. This approach allows the characterization of children's unique experience from their point of view about the situation experienced and their needs. In this perspective, the option for qualitative approach was adequate because it allows the understanding of the satisfaction and dissatisfaction experience with pain management in the pediatric emergency department based on children's own reports.

Patient satisfaction is defined as the relationship between personal expectations and the perception of care effectively received $^{(18)}$. The American Nurse Association (ANA) defines patient satisfaction as "the measurement of the patient's or the relative's opinion about the care received by the nursing team" ${ }^{(19)}$. With Donabedian, patient satisfaction was included in the evaluation of health quality as an indicator of outcome of the care provided ${ }^{(20)}$. Based on the assumption that references of the quality concept change over time, it is important to know and evaluate patients' and professionals' perception about quality in order to effectively target strategies and actions, meet their expectations and enable a more convicted and compatible decision making with the context and objectives of the health institution.

In this sense, we used an approximation of the Donabedian model as theoretical reference ${ }^{(20)}$. It is a conceptual model that provides a design for the evaluation of quality of health care from three dimensions, namely: Structure, Process and Results. Structure refers to the environment where the child was treated; Process refers to the relationship between the health team and the child; and the Results dimension refers to pain relief.

The study was conducted in the pediatric emergency department of a hospital located in the city of São Paulo. The data collection period was between October 2016 and May 2017.

The study participants were children who used the pediatric emergency department and were in school phase, that is, in the age group of 6 to 12 years old.

The inclusion criteria of participants were children attended at the emergency department with pain complaints who did not present any more pain after receiving medication, and that were able to verbalize. Exclusion criteria were children unable to participate due to physical fatigue and/ or discomfort.

The contact with children and their relatives occurred during care in the observation room of the pediatric emergency department. While the child received pain medication, the researcher first talked to the family about the study objectives, clarified doubts and made the invitation. Then, was requested authorization for the child's participation in the study.

During the time of observation, the researcher followed the evolution of children's pain picture. When children were pain-free, they were invited to participate in the study. The researcher read the Informed Consent form for the parents 
and the Term of Agreement for the children for their participation in this study, and handed the printed copy of the documents to family members. During reading, important points such as voluntary participation, withdrawal at any time of the interview and confidentiality were reinforced.

The interview focused on knowing the children's perspective regarding their satisfaction and dissatisfaction with pain management, and followed the guiding question: 'How was the care provided for your pain in the pediatric emergency department?'. This step lasted approximately 15 minutes. The interviews took place in medical offices that were not being used at that moment, and were recorded and transcribed by the researcher immediately after their performance in order to ensure no loss of information. Data collection was performed until repetition of contents of participants' speeches, and the Thematic Analysis approach was used for data analysis ${ }^{(11-17)}$.

Participants were identified with the word 'Child', and the interviews were identified with a number, hence the final configuration was 'Child 1', for example.

\section{ETHICAL ASPECTS}

This study was based on Resolution number 466 of December 12, 2012 of the National Health Council, which regulates research with human beings ${ }^{(21)}$. It was approved by the Research Ethics Committee of the School of Nursing of the Universidade de São Paulo (EEUSP) under number 1.508.647 and also by the Ethics Committee of the participating institution under number 1.639.451.

\section{RESULTS}

Nineteen children aged between 6 and 12 years were interviewed, out of which nine were boys (47\%) and ten were girls (53\%). Regarding the age group, one child was 6 years old, two were 7 years old, two were 8 years old, four were 9 years old, two were 10 years old, six were 11 years old and two were 12 years old. Fourteen mothers, seven fathers and one grandmother were accompanying the children at the time of the interview.

According to the risk classification adopted by the PED, 17 children (89\%) were classified as yellow risk, and two (11\%) as green risk. After medical consultation, children went to the observation room, where pain management and pharmacological management were performed appropriately according to the pediatric age group.

Concerning children's complaints of pain, eight (42\%) had abdominal pain, eight (42\%) had headache, and three (16\%) came to the PED with complaints of abdominal pain and headache.

The results were organized in two themes based on children's speeches, namely: Theme 1 - Satisfaction perceived by children regarding pain management in the pediatric emergency department, which included the three following subthemes: Priority care and quick pain relief, Basic needs met and Embracement by the team; and Theme 2-Dissatisfaction perceived by children regarding pain management in the pediatric emergency department, which included the three following subthemes: Delay in pain relief, Painful procedures and Uncomfortable environment.
Theme 1: Satisfaction PERCEIVED by CHILDREN REGARDING PAIN MANAGEMENT IN THE PEDIATRIC EMERGENCY DEPARTMENT

\section{PRIORITY CARE AND QUICK PAIN RELIEF}

When children reached the emergency department feeling pain, they felt uncomfortable with that symptom and wanted to eliminate the unpleasant sensation as quickly as possible. During the first moment of care in the triage, it is important that nurses determine the correct flow of care and prioritize if necessary, so that children in pain do not wait long to be attended. For children, one of the most important issues was pain relief, and for that to happen, analgesia should be administered as soon as possible.

They helped a lot here. They saw I was unwell, prioritized the care, brought me in a wheelchair 'cause they saw I couldn't walk. And they supported me, it was very good, they accompanied me a lot, really (Child 4).

It was good, 'cause when I got here, I came up here and they already put me on a drip, with medicine (Child 15).

Yeah, I think it was good. (...) quick and healed all the pain. (...) it was fast, was very fast. (...) it was quick to take the medicine. (...) to relief the pain was a bit longer, but it was quick (Child 11).

\section{BASIC NEEDS MET}

When the child is in pain, all attention is focused on the painful feeling that prevents them from performing common activities such as walking, feeding, and even resting. With relief of discomfort, children felt sleepy and hungry again. Meeting these needs was also part of the care and improved the assistance by making it more comfortable for the child. I liked sleeping. (...) I got enough sleep here. I was able to sleep after the pain got better (Child 6).

When I slept. (...) Because it was good. (...) I had not been able to sleep at home (Child 19).

The food, because it was good. (...) I ate biscuits and had juice (Child 12).

\section{I liked the food better (Child 3).}

\section{EMBRACEMENT BY THE TEAM}

When children arrived at the emergency department, they were frail, in pain, and in an unfamiliar environment. They passed through various places, such as triage, reception, and the doctor's office before receiving some pain relief. The time spent by children in the observation room for receiving pain medication, waiting until feeling better and for test results, and until their reevaluation, varied according to each one. Thus, during their stay in the room, children expected to be served well. For them, this meant that health professionals were calm, attentive, and communicated with a language they were able to understand. The attention and affection given by the health team helped in understanding, collaboration and quicker recovery of children's pain. 
(...) they put a needle, and it didn't hurt, and they were very attentive to me. Because everything we asked for they brought, we asked for snacks, a blanket, we asked for many things, and they brought everything (Child 6).

They treated me well and welcomed me well, too. They took care of me (Child 10).

I thought they served me well, they were very calm with me (Child 2).

\section{Theme 2: Dissatisfaction PeRCeIVed by ChILDReN REGARDING PAIN MANAGEMENT IN THE PEDIATRIC EMERGENCY DEPARTMENT}

\section{DELAY IN PAIN RELIEF}

When children arrive in the observation room in pain, they hope this pain will be eliminated and to this end, the pain relief process must be expedited. Delays in venipuncture or medication administration increased discomfort. In addition, children had to wait for the effect of medication and the alleviation of pain. During that time, children continued to have a poor experience. In some cases, the improvement occurred after the first medication, and in others, only after several associated medications.

I did not like the delay, I was in a lot of pain. (...) When I arrived, it took me a long time to get the medicine. (...) The other time it was much faster. (...) Because I arrived and I still had to wait a long time until they pricked me. (...) I think I was much stronger this time (Child 9).

I did not like the headache. (...) I thought it took long to pass the pain (Child 13).

\section{PAINFUL PROCEDURES}

All interviewed children were already in pain and for its alleviation, they had to undergo the invasive venipuncture procedure, which was considered painful for most children. They were apprehensive, either because they had previous unpleasant experiences or because they did not know the procedure. Furthermore, the procedure was considered a troubling moment by children because there was no guarantee of success in the first attempt.

In addition to the painful procedure, children also felt anxious to be in a situation of investigation without the results and not knowing what would happen, because they could return home or stay hospitalized.

I don't like going to the doctor, (...) I don't like to get pricked. Because it hurts a lot. (...) I'm afraid when it's time to get my arm pricked. As I haven't come to the hospital for a long time, I was scared at the time of getting my arm pricked (Child 15).

I didn't like the needle, because I've never put a needle, a drip, nothing. (...) I didn't like to get pricked, it hurts. I wish there was no needle (Child 19).

\section{UNCOMFORTABLE ENVIRONMENT}

The environment was a very important aspect during children's recovery. The physical space, from the organization of litters and objects to the attention of employees and other patients in the sector have influenced the experience within the hospital setting.

The environment where children received intravenous medications (the observation room) is sometimes noisy given the large number of children, and calm at other times, but unpredictable. The excessive lighting can also cause discomfort in some cases.

Furthermore, pediatric and adult patients are more exposed to common areas in the emergency department. For children, it was a scary place with situations they have never experienced in other places.

I think it was when, when we were doing the ultrasound, and we were waiting to do it and there were many litters, then, I was scared 'cause I don't like to see it. (...) People, they were like, they had some scary things (Child 5).

There was the problem of light. That light in the middle, it was right at the height of the small net and it was bad (Child 4).

\section{DISCUSSION}

This study sought to understand satisfaction and dissatisfaction with pain management in the pediatric emergency department from children's point of view. Corroborating our findings, results from another study demonstrated the importance of listening to children and knowing their experience from their speeches in order to improve care according to their needs ${ }^{(5)}$.

By analyzing children's narratives in the light of the model composed of dimensions of Structure, Process and Results ${ }^{(20)}$, the results observed were close to this triad, although not necessarily in this order.

\section{SATISFACTION PERCEIVED BY CHILDREN ABOUt PAIN MANAGEMENT IN THE PEDIATRIC EMERGENCY DEPARTMENT}

As children arrive at the pediatric emergency department in pain, fast care was considered important for them. Priority makes the flow of care faster, as well as medical care and, consequently, pain relief. This is a relevant item, especially on busier days in the emergency department. Differently from this study, in another study, child satisfaction did not correlate with waiting time ${ }^{(22)}$.

When arriving at the pediatric emergency department, children pass for the hospital's triage system, in which they are classified according to the risk presented by the clinical picture. The hospital adopts the Canadian classification protocol ${ }^{(23)}$, in which green classification is for children's assistance within two hours, and yellow classification is for those who need care within 30 minutes of their admission to the PED. Note there is no pain medication protocol in the triage in this institution.

In this study, children associated rapid pain relief at the emergency department with satisfaction. Children who were in pain sought their relief. Other studies show the importance given by children to stop the pain or its alleviation during hospital treatment. For them, pain control in the emergency department was also related to satisfaction $^{(5,22)}$. 
Children's satisfaction for having their basic needs met was also a positive highlight in our findings. They mentioned food and rest as important during the care. With relief of discomfort, children were able to resume their activities, felt sleepy and hungry again, because they were not bothered by pain anymore. Sleep was one of the most cited items by children, because at home, when they felt uncomfortable with pain, they could not sleep well. However, after pain relief at the hospital, they could rest. During the time in observation, and with improvement of pain, hunger was inevitable. In addition, children felt more comfortable to eat. The study also mentions attention to basic needs as essential for children in pain $^{(3)}$.

Killing pain not only with medications but also with emotional support, makes children feel relieved. Thus, accompaniment while they are under observation is vital for management of pain, as well as the creation of a comfortable environment, which helps them to get distracted, and for offering help when necessary.

In this sense, the Results dimension ${ }^{(20)}$, which refers to children's pain relief and the effects of health care on their behavior and knowledge, makes children feel satisfied and corroborates the results of the present study.

Embracement by the team was another important aspect mentioned and considered relevant in this study. For children, attention and care of the health team were essential, because this helped with understanding the situation experienced, facilitated collaboration as they were able to understand what was being done and how, which favored faster pain relief. In a study on children's perspective of pain management in the pediatric emergency department, children indicated the importance of active listening and questioning directed at them ${ }^{(3,5)}$.

Communication is part of user embracement and essential for dialogue between health professionals and children. In this study, it was positively highlighted by children. However, note that children emphasized that the communication should be clear and there should be understanding. Moreover, communication has the power to calm anxious children and make them understand the treatment process in the emergency department. Understanding what the doctor says, the actions taken and the test results makes children feel safe throughout the process. Direct communication by asking what children are feeling, if they are getting better, and if there is another way to make them feel better is important in recovery and faster pain relief.

The Process dimension ${ }^{(20)}$ refers to relationships between patients and professionals throughout the provision of healthcare, and confirms the results of this study. The Process is the sum of all actions comprising health, which includes diagnosis, treatment, preventive care and patient's education, as well as actions taken by patients or their family members.

\section{DisSATISFACTION PERCEIVED BY CHILDREN ABOUT PAIN MANAGEMENT IN THE PEDIATRIC EMERGENCY DEPARTMENT}

In this study, children negatively stressed the long waiting time until receiving pain relief medication. For them, feeling pain and suffering until pain relief is very difficult.
Corroborating our findings, the literature indicates that most children are dissatisfied with treatment when there is delay in pain relief ${ }^{(5)}$.

Another negative point was the invasive procedure of venipuncture that was considered painful by most children. Painful procedures are often feared and distressing for children. Special attention should be given to children by preparing them for the procedures. To this end, the family and other team members play a key role in this preparation and reduce their anxiety ${ }^{(24-25)}$. The active participation of children in their care should be encouraged both by professionals and their families, hence taking into consideration their right to voice and participation in health care ${ }^{(26)}$.

The Results dimension ${ }^{(20)}$ proposed by the model was not contemplated neither in the delay in pain relief nor in painful procedures.

The environment was another aspect contributing to dissatisfaction with pain management of children. The physical space and its organization influenced the experience of children and their companions within the hospital environment. In this study, the room lighting caused discomfort in children, and may have been responsible for the delay in pain relief. In addition, a child was scared to perform an imaging examination outside the PED area, because that is a part of the hospital where adult patients stay on litters in corridors in unknown situations to the child. The environment should favor children's recovery with comfortable beds, pleasant temperature, little noise and low light. However, when the environment is common to all without individual separation, often there is no possibility to contemplate all the mentioned items.

From the point of view of the Structure dimension ${ }^{(20)}$, which outlines the context in which care is provided, including physical and human resource characteristics, the physical structure, equipment and inputs, the quantity and qualification of professionals and financial resources available for maintaining infrastructure and technology for services viability and the uncomfortable environment, determined children's dissatisfaction with pain management within the hospital setting. Thus, this dimension was not observed in our findings.

Some limitations were observed during the analysis of results, among which the fact of conducting the study only in one hospital with a specific age group. Therefore, more research on this topic should be conducted in private and public hospitals, mainly in Brazil, for better understanding their realities and specificities. This will bring improvement possibilities according to each reality for pain management in pediatric emergency departments. These places are really important because of the high number of children that seek care because of pain complaints, and who can undergo numerous painful procedures.

\section{CONCLUSION}

This study showed children's satisfaction and dissatisfaction with pain management in the pediatric emergency department from the perspective of qualitative research. It allowed the increase of knowledge on this subject by showing important aspects in order to consider the service satisfactory from the point of view of who is being cared for. 
Children have highlighted important points considered as satisfaction during their experience in the emergency department. Such points were beyond the elimination of pain itself, namely: priority care and quick pain relief, embracement by the staff and basic needs met.

In an unpredictable environment such as the emergency department, where health professionals interrupt what they are doing at any time in order to attend an emergency, the dialogue between professionals, families and children being cared for is essential.
This study also revealed children's dissatisfaction with the delay in pain relief, painful procedures, and the uncomfortable environment.

Importantly, this was the first study conducted in Brazil addressing the issue of children's satisfaction and dissatisfaction with pain management in the pediatric emergency department. It contributes to improve the clinical practice with the aim of care excellence by giving voice to children so they tell their pain experience, and by appreciating children's embracement by the health team, and the communication between them.

\section{RESUMO}

Objetivo: Compreender a satisfação e a insatisfação da criança acerca do manejo da dor no pronto-socorro infantil. Método: Estudo exploratório e descritivo, com abordagem qualitativa realizado com crianças entre 6 e 12 anos de idade, envolvendo entrevista semiestruturada e análise temática dos dados. Resultados: Foram entrevistadas 19 crianças. Os resultados foram organizados em dois temas: Tema 1 - A satisfação percebida pela criança acerca do manejo da dor, composto de três subtemas: Atendimento prioritário e alívio rápido da dor, Necessidades básicas atendidas e Acolhimento pela equipe; e Tema 2 - A insatisfação percebida pela criança acerca do manejo da dor, composto de três subtemas: Procedimentos dolorosos, Ambiente desconfortável e Demora em aliviar a dor. Conclusão: Observou-se que a satisfação da criança acerca do manejo da dor constituiu-se em muito mais do que o alívio da dor, ou o atendimento prioritário, englobou também o ambiente do pronto-socorro infantil e o acolhimento pela equipe. É recomendado que o cuidado seja direcionado às singularidades das crianças, ou seja, a um cuidar construído a partir da compreensão da experiência sob o ponto de vista infantil.

\section{DESCRITORES}

Dor; Criança; Manejo da Dor; Satisfação do Paciente; Enfermagem em Emergência; Enfermagem Pediátrica.

\section{RESUMEN}

Objetivo: Comprender la satisfacción y la insatisfacción del niño acerca del manejo del dolor en urgencias infantiles. Método: Estudio exploratorio y descriptivo, con abordaje cualitativo llevado a cabo con niños entre 6 a 12 años de edad, involucrando entrevista semiestructurada y análisis temático de los datos. Resultados: Fueron entrevistados 19 niños. Los resultados fueron organizados en dos temas: Tema 1 - La satisfacción percibida por el niño acerca del manejo del dolor, compuesto de tres subtemas: Atención prioritaria y alivio rápido del dolor, Necesidades básicas atendidas y Acogida por el equipo; y Tema 2 - La insatisfacción percibida por el niño acerca del manejo del dolor, compuesto de tres subtemas: Procedimientos doloridos, Ambiente incómodo y Demora en aliviar el dolor. Conclusión: Se observó que la satisfacción del niño acerca del manejo del dolor se constituye en mucho más que el alivio del dolor, o la atención prioritaria, abarcó también el ambiente de urgencias infantiles y la acogida por el equipo. Se recomienda que el cuidado se dirija a las singularidades de los niños, es decir, a un cuidado construido mediante la comprensión de la experiencia desde el punto de vista infantil.

\section{DESCRIPTORES}

Dolor; Niño; Manejo Del Dolor; Satisfacción del Paciente; Enfermería de Urgencia; Enfermería Pediátrica.

\section{REFERENCES}

1. Manocha S, Taneja N. Assessment of paediatric pain: a critical review. J Basic Clin Physiol Pharmacol. 2016;27(4):323-31. DOI: 10.1515/ jbcpp-2015-0041

2. Thrane SE, Wanless S, Cohen SM, Danford CA. The assessment and non-pharmacologic treatment of procedural pain from infancy to school age through a developmental lens: a synthesis of evidence with recommendations. J Pediatr Nurs. 2016;31(1):e23-32. DOI: 10.1016/j. pedn.2015.09.002

3. Byczkowski TL, Fitzgerald M, Kennebeck S, Vaughn L, Myers K, Kachelmeyer A, et al. A comprehensive view of parental satisfaction with pediatric emergency department visits. Ann Emerg Med. 2013;62(4):340-50. DOI: 10.1016/j.annemergmed.2013.04.025

4. Gill M, Drendel AL, Weisman SJ. Parent satisfaction with acute pediatric pain treatment at home. Clin J Pain [Internet]. 2013 [cited 2017 May 19];29(1):64-9. Available from: https://www.ncbi.nlm.nih.gov/pmc/articles/PMC4439581/

5. Weingarten, L, Kircher J, Drendel AL, Newton AS, Ali S. A survey of children's perspectives on pain management in the Emergency Department. J Emerg Med. 2014;47(3):268-76. DOI: 10.1016/j.jemermed.2014.01.038

6. Souza C, Chianca LM, Diniz AS, Chianca TCM. Principais queixas de pacientes de urgência segundo o protocolo de classificação de risco de Manchester. Rev Enferm UFPE on line. 2012;6(3):540-8. DOI: 10.5205/reuol.2163-16218-1-LE.0603201207

7. Wier L, Yu H, Owens PL, Washington R.; Agency for Healthcare Research and Quality. Overview of children in the Emergency Department. Statistical Brief \#157 [Internet]. Rockville, MD; 2013 [cited 2017 Mar 10]; Available from: https://www.hcup-us.ahrq.gov/reports/statbriefs/ sb157.pdf

8. Vale APF, Silva VR, Mendonça BOM, Barros EJ, Mota RM, Oliveira VCC, et al. Caracterização do perfil de atendimento no serviço de emergência pediátrica de um hospital no interior de Goiás. Rev Eletr Faculd Montes Belos [Internet]. 2015 [citado 2017 ago. 07];8(4):32-56. Disponível em: http://revista.fmb.edu.br/index.php/fmb/article/view/178/151

9. Jadav MAR, Lioyd G, McLauchlan C, Hayes C. Routine pain scoring does not improve analgesia provision for children in the emergency department. Emerg Med J. 2009;26(10):695-7. 
10. Margaret N, Clarck T, Warden C. Patient satisfaction in the emergency department- a survey of pediatric patients and their parents. Acad Emerg Med. 2002;9(12):1379-88.

11. Hungler B, Beck C, Polit, D. Fundamentos de pesquisa em enfermagem: métodos, avaliação e utilização. Porto Alegre: Artmed; 2004.

12. Creswell JW. Qualitative inquire and research design: choosing among five approaches. 2th ed. Thousand Oaks: Sage; 2007.

13. Rubin HJ, Rubin IS. Qualitative interviewing: the art of hearing data.Thousand Oaks: Sage; 1995.

14. Sandelowski M, Barroso J. Writing the proposal for a qualitative research methodology project. Qual Health Res. 2003;13(6):781-820.

15. Sandelowski M, Barroso J. Classifying the findings in qualitative studies. Qual Health Res. 2003;13(7):905-23.

16. Sandelowski M, Leeman J. Writing usable qualitative health research findings. Qual Health Res. 2012;22(10):1404-13.

17. Braun V, Clarke V. Using thematic analysis in psychology. Qual Res Psychol. 2006;3(2):77-101.

18. Risser N. Development of an instrument to measure patient satisfaction with nurses and nursing care in primary care settings. Nurs Res.1975;24(1):45-51.

19. American Nursing Associations. 10 ANA quality indicators for acute care settings. Healthcare Benchmarks. 1999;6(12):138-9.

20. Donabedian A. La calidad de la atención médica, definicion y metodos de evaluacion. México: Prensa Medica Mexicana; 1984.

21. Brasil. Ministério da Saúde; Conselho Nacional de Saúde. Resolução n. 466, de 12 de dezembro de 2012. Estabelece diretrizes enormas regulamentadoras de pesquisas envolvendo seres humanos [Internet]. Brasília; 2012 [citado 2016 jun. 7]. Disponível em: http://bvsms. saude.gov.br/bvs/saudelegis/cns/2013/res0466_12_12_2012.html

22. Byczkowski TL, Gillespie GL, Kennebeck SS, Fitzgerald MR, Downing KA, Alessandrini EA. Family-centered pediatric emergency care: a framework for measuring what parents want and value. Acad Pediatr. 2016;16(4):327-35.

23. Warren DW, Jarvis A, LeBlanc L, Gravel J; CTAS National Working Group. Revisions to the Canadian Triage and Acuity Scale paediatric guidelines (PaedCTAS). CJEM. 2008;10(3):224-32.

24. Association of Paediatric Anaesthetists of Great Britain and Ireland. Good practice in postoperative and procedural pain management. Pediatr Anaesth. 2012;22 Suppl 1:1-79.

25. Ali S, Weingarten LE, Kircher J, Dong K, Drendel AL, Rosychuk RJ, et al. A survey of caregiver perspectives on children's pain. management in the Emergency Department. CJEM. 2016;18(2):98-105.

26. Bubadué RM, Cabral IE, Carnevale FA, Asensi FD. Análise normativa sobre a voz da criança na legislação brasileira de proteção à infância. Rev Gaucha Enferm [Internet]. 2016 [citado nov. 24];37(4):e58018. Disponível em: http://www.scielo.br/scielo.php?pid=S1983-14 $472016000400407 \&$ script=sci_abstract\&tlng=pt 